RESEARCH ARTICLE

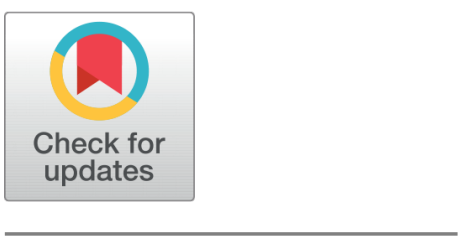

OPEN ACCESS

Received: 20-02-2020

Accepted: $31-05-2020$

Published: 20-06-2020

Editor: Dr. Natarajan Gajendran

Citation: Hussain S, Khoso ID, Qureshi F (2020) Impact of mergers and acquisitions on shareholders' wealth: a study of Telecom sector of Pakistan. Indian Journal of Science and Technology 13(21): 2104-2110. https://doi.org/ 10.17485/IJST/v13i21.615

*Corresponding author. Salar Hussain

Institute of Business Administration, University of Sindh, Jamshoro, Tel.: +923342145560

Shaheed Benzair Bhutto University, Shaheed Benazirabad, Shaheed Benazirabad

salarhussain@sbbusba.edu.pk

Funding: None

Competing Interests: None

Copyright: (c) 2020 Hussain, Khoso, Qureshi. This is an open access article distributed under the terms of the Creative Commons Attribution License, which permits unrestricted use, distribution, and reproduction in any medium, provided the original author and source are credited.

Published By Indian Society for Education and Environment (iSee)

\section{Impact of mergers and acquisitions on shareholders' wealth: a study of Telecom sector of Pakistan}

\author{
Salar Hussain ${ }^{1,2 *}$, Imam-ud-Din Khoso ${ }^{1}$, Fiza Qureshi ${ }^{1}{ }^{1}$ \\ 1 Institute of Business Administration, University of Sindh, Jamshoro, Tel.: +923342145560 \\ 2 Shaheed Benzair Bhutto University, Shaheed Benazirabad, Shaheed Benazirabad
}

\section{Abstract}

Objectives: This study aims to investigate the impact of mergers and acquisitions related events on the shareholders' wealth in Telecom sector of Pakistan. Statistical analysis: Event study methodology has been used to achieve this objective, in which, the short term and long term performance of firms are measured. For short term performance, Abnormal Returns (AR) and Cumulative Abnormal Returns (CAR) are measured while to determine long term performance, Buy-and-Hold Abnormal Returns (BHAR) are measured. Findings: The results revealed that the occurrence of these events has negatively affected the shareholders' wealth and the financial market did not respond to these events in the telecom sector of Pakistan. Application: The study suggests that the telecom sector should choose different strategies to gain market share, to increase revenues, to gain a competitive edge and to diversify risk.

Keywords: Mergers; acquisitions; event study; abnormal returns; cumulative abnormal returns; buy-and-hold abnormal returns

\section{Introduction}

Mergers and acquisitions (M\&As) have gained considerable interest in academic research. Most of these studies focus on the short term impact of these events on the stock market returns. While some of the studies focused on the longer-term impact of these events on the stock returns. Overall efforts have been made to measure short term and long term post-merger performance and to improve measurement techniques, to handle benchmark issues and to improve test statistics ${ }^{(1)}$.

Merger is the strategy to combine two or more organizations while in the acquisitions, organizations combine in a way that the identity of one entity remains while other's identity is dissolved. Motives behind the mergers and acquisitions (M\&As) is to enhance the market share, to boost revenues, to gain competitive advantage, and to diversify risk and products ${ }^{(2)}$. Acquisition or takeover is mostly the purchase of capital shares of the company. Further, acquisitions are also exaggerated if any individual having the majority interest in the affairs of the management ${ }^{(3)}$. M\&As are equally important for companies to achieve growth, reduce costs, acquiring assets and to expand their markets resulting in higher profitability and returns ${ }^{(4)}$. Due to the global financial crises, the rate of M\&As has increased just not because to gain competitive advantage 
but also maintaining the firm's existence and grip in the industry, which has significantly transformed the landscape of businesses $^{(2)}$.

The M\&As strategies are less practiced in developing countries and the same is the case with Pakistan, so there is limited literature available. In the early nineties, these strategies were not used but now M\&As have gain importance for the growth and expansion of the businesses. Between 1991 to 2018, around six hundred and forty-seven events had occurred in the financial as well as in the non-financial sectors of Pakistan. These events occurred to gain competitive advantage in non-financial sectors while the changes in regulation by the central banks urged the financial sectors for the occurrence of M\&As to improve stability and to gain a competitive edge ${ }^{(5)}$.

According to our best estimate, no such study has been conducted in the Telecom sector of Pakistan to analyze the impact of the occurrence of M\&As on shareholders' wealth. This study will analyze the impact of these events on the returns. Earlier a study was conducted to analyze the impact of M\&As on the financial performance of firms by analyzing the financial ratios of the acquiring firm. The results of that study suggested the financial performance of acquired firm Pakistan Telecommunication Limited (PTCL) neither improved nor declined ${ }^{(6)}$. This study will fill this research gap and re-assess the influence of M\&As on firms' performance by analyzing the share value of the firms in the Telecom sector. Secondly, this study will provide future guidelines for the shareholders for investing in the firms during the regime of M\&As in telecom and other sectors of Pakistan.

The Telecommunication industry is rapidly developing industry of the corporate world. The telecommunication industry is competitive market in which the low prices enhance quality and innovation has increased chances for increased for firms to expand their markets. Recently firms have used various strategic techniques to enter the new markets which include mergers, acquisitions and alliances. In the telecom sectors, there were two waves of M\&As. The first wave was observed between 1999 to 2000 which was a technology bubble and led towards the building of scale in the telecom sector. From 2005 to 2007, the second wave was observed, which led to the consolidation between the European broadband sector and the US mobile market ${ }^{(7)}$.

The most common cited incentive for two companies to merge are the possible synergies, however, the concept is very broad and wide in meaning. Synergies in simple terms are comprehended to take place when two firms produce or generate increased values for the shareholders of the company which operates collectively than operating separately. Mellen and Evans ${ }^{(8)}$ define it as "a business combination that makes two plus two equal to five". Furthermore, synergies of two types can differentiate fundamentally, financial and operational. The operational synergies are attained through economies of scale and economies of scope. Similarly, onthe other hand, the financial synergies are an indication to identify the influence of the acquirer bounded within the scope of its cost of capital.

Many empirical researches are attempted for merger activity in the exploration of wealth effect mainly in developed countries especially the UK and the USA. Studies for analysis of wealth creation with the help of mergers comprises different and several measures. Among studies, one is event study methodology which determines the shorter and medium-term stock performance of the merged, bidder and target entity. This methodology is based on assumptions of the market which assumes that stock prices fluctuate with time to time and in a fair manner towards newer information ${ }^{(9)}$. Other studies follow accounting performance indicators such as return on equity \& several cash flow measures for the comparison between pre-merger and post-merger performances. These studies endorse losses or gains by merger appear in the firm's accounting records ${ }^{(10)}$. Both studies vary in results.

During 1981 to 1995 , Ghosh ${ }^{(11)}$ enquired about the performance and progress of 315 US mergers. He took in action control firms as a benchmark as a substitute for industry median firms contrary to Healy ${ }^{(12)}$. The researcher chose control firms in accordance with the performance and total assets amount from pre-mergers years as a benchmark. The study also specified the methodology used by Healy ${ }^{(12)}$ and was unable to recognize better operating performance. Sharma ${ }^{(13)}$ also practiced the methodology already used by Healy ${ }^{(12)}$. Thirty-six manufacturing firms were used for analyzing the post-acquisition performance in Australia from 1986 to 1991, in which they used the matching principle based on assets' size and industry to justify the controlling factors of industry and economy. However, significant improvements in post-acquisition operating performances were not observed by them. Pawaskar ${ }^{(14)}$ did an investigation in India using the methodological system generated by $^{(15)}$ and ${ }^{(16)}$ to analyze and observe the pre-merger and post-merger operating improvements and performances of acquiring firms. He also remarked merger-induced alterations after using a sample of thirty-six mergers during 1992-1995.No improvement or optimization in corporate performance post-merger revealed in findings of the study. Control ground used and small size of sample encompasses some certain limitations in study.

In an empirical research-based survey of 152 companies, Rani, Yadav ${ }^{(17)}$ had observed that the primary goals of mergers in India from 2003 to 2008 had been to take benefits and privileges of synergies. Corporate mergers in India would help indicate operating economies, financial economies and increasing market share in order of essentiality as the concerned synergies.

Merger and acquisition practices in Pakistan are mainly trivial; however, the data suggests that it's being conducted in an unnoticeable pace. The prime objective of that study was to examine forty-five Merger and acquisition (M\&A) cases reported 
between 2004 and 2015 in multiple sectors of Pakistan. The findings projected that in between the estimation windows of eleven days, acquired firms neither destroyed nor created value for the shareholders ${ }^{(18)}$. The study was conducted to know the impact of M\&As on the performance of firms. The study aimed to analyze the pre and post-impact of M\&As on bidding banks in Pakistan. Moreover, to analyze factors of firm, industry and country level affect the financial performance of M\&A firms. For this purpose, selected 51 listed bidder banks during 2002-2013 and used descriptive statistics, Z test, and regression models for analysis. Results showed that M\&A failed to produce fruitful results for bidding banks in Pakistan. Hence, recommended that direction and practical implications are provided to banks, investors, and policymakers to get knowledge about M\&A to secure their investment from financial losses ${ }^{(19)}$.

A study was conducted in the telecom sector to analyze the performance of 44 events in terms of diversification and firm size on market valuation. An event study methodology was used to test the hypotheses. The results of the study concluded that the occurrence of M\&As mostly affected positively on the market value of the firms ${ }^{(20)}$. An examination was carried out to empirically analyze the reaction of the price of the stock during the announcement of events in both the acquiring as well as target firms. Further to this, the insider information role was also explained and verified before the deal's announcement. The event study methodology was used to analyze the impact. The study analyzed that the prices went up high before the announcement period showing that there was leakage of the information as there was an expectation of the occurrence of certain positive news. Further, results showed that post-period prices decreased for the acquired firms ${ }^{(21)}$.

To identify the influence of M\&As, the post- mergers and acquisitions regime was analyzed in detail for the various companies of Pakistan. In which, different 8 episodes of M\&As between 2000 to 2002 were selected. In the said cases, the majority of merger companies of the given study were of the top Pharmaceutical industry and bankers. All of these said companies were itemized on Karachi Stock Exchange. With the application of even study method, an impact on the share prices of these companies was reported. Interestingly, the results projected that after one month following the merger and acquisition, two companies reported a negative impact whereas, the remaining five companies indicated positive results in the prices of share. However, one company was reported to witness no significant change. Nonetheless, the results conclusively projected positive impacts on the share prices of the M\&A companies ${ }^{(22)}$.

\section{Research Methodology}

The objective of this study is to find the impact of mergers and acquisitions on the stock market returns, which will be achieved with the help of event study technique as introduced Dodd and Warner ${ }^{(23)}$ and Brown and Warner ${ }^{(24)}$ and extended by Barber and Lyon ${ }^{(25)}$. The event study technique helps to analyze the short term and long term stock performance of the acquired firms. This technique involves two-step process. First, the short term announcement effect is measured with the help of Cumulative Abnormal Returns (CAR). Second, the long term stock returns performance is measured with the help of Buy-and-Hold Abnormal Returns (BHAR). In the financial researches, this approach is used ${ }^{(26)}$, Further, this technique is also used in M\&As so that short term and long term impact of M\&As can be analyzed and these synergies impact on the firm performance in terms of stock returns could be assessed ${ }^{(27)}$. The market model has been employed to estimate abnormal returns in the event window of 91 days.

$$
A R_{i, t}=R_{i, t}-\left(\widehat{a}_{i}+\widehat{B}_{i} R_{m, t}\right)
$$

Here, the return of company is mentioned by $\mathrm{Ri}, \mathrm{t}$, $\mathrm{i}$ representing company and $\mathrm{t}$ trading day. Benchmark index which is KSE 100 index is represented by $\mathrm{Rm}, \mathrm{t}$. Here the $\alpha \mathrm{i}$ and $\beta \mathrm{i}$ represent the regression coefficients of the $\mathrm{i}$ company. The CAR for the companies in 91 days windows is calculated with the formula below.

$$
C A R_{i \cdot[}\left[r_{1}, r_{2}\right]=\sum_{t=r_{1}}^{r_{2}}\left[R_{i, t}-\left(\widehat{a}_{i}+\widehat{B}_{i} R_{m, t}\right)\right]
$$

After that, test statistics are computed by the following equation to check whether the averages of the abnormal returns different from zero.

$$
\mathrm{TEST}=((\Sigma \mathrm{AR}) / \mathrm{N}) /(\mathrm{AR}-\mathrm{SD} / \operatorname{sgrt}(\mathrm{N}))
$$

Where AR is the abnormal return, $\mathrm{N}$ is the number of days in the event window and AR_SD is the abnormal return standard deviation.

In the long run, the abnormal returns for 90, 180, 270 and 360 days were analyzed with the help of BHAR methodology in which KSE 100 index was taken as a benchmark for market returns. Consequently, the market-adjusted BHAR can be calculated as:

$$
\operatorname{BHAR}_{i,\left[r_{1, r_{2}}\right]}=\prod_{r_{1}}^{r_{2}}\left(1+R_{i, t}\right)-\prod_{r_{1}}^{r_{2}}\left(1+R_{m . t}\right)
$$


Where Ri,t is the return of company $\mathrm{i}$ on day $\mathrm{t}$ and $\mathrm{Rm}, \mathrm{t}$ is the return of the KSE 100 index benchmark index on day $\mathrm{t}$.

This analysis is carried out with the help of Stata and with the help of the event study tool online version ${ }^{(28)}$. The criterion for selection of companies was based on:

- The acquirer companies are listed on Pakistan Stock Exchange (PSX).

- Both the Acquirer and target companies are of the same sectors which are under study.

- Merger date and sufficient share price was data available on PSX.

The M\&As deals to be analyzed for the telecom sector selected on above criterion are mentioned in the table below in Table 1 .

Table 1. Telecom sector M\&As

\begin{tabular}{lllll}
\hline Event & Acquirer & Target & Type & Date of M\&As \\
\hline E1 & $\begin{array}{l}\text { Pakistan Telecommunication Com- } \\
\text { pany Limited. }\end{array}$ & $\begin{array}{l}\text { DVCOM Data (Pvt) } \\
\text { Limited }\end{array}$ & Acquisition & $15 / 04 / 2015$ \\
E2 & $\begin{array}{l}\text { Pakistan Telecommunication Com- } \\
\text { pany Limited. }\end{array}$ & $\begin{array}{l}\text { Maskatiya Communica- } \\
\text { tions (Pvt) Limited }\end{array}$ & Acquisition & $25 / 03 / 2010$ \\
E3 & Worldcall Telecom Limited & $\begin{array}{l}\text { WorldCall Broadband } \\
\text { Limited }\end{array}$ & Merger & $09 / 06 / 2006$ \\
E4 & Worldcall Telecom Limited & $\begin{array}{l}\text { WorldCall Communica- } \\
\text { tion Limited }\end{array}$ & Merger & $09 / 06 / 2006$ \\
& & WorldCall Multimedia & Merger \\
E5 & Worldcall Telecom Limited & Limited & $09 / 06 / 2006$ \\
\end{tabular}

Source: Competition Commission of Pakistan and Pakistan Stock Exchange

\section{Data Analysis \& Interpretation}

\subsection{Short Term Analysis}

Below Table 2 show the negative Abnormal and Cumulative Abnormal returns for the event 1 on the announcement date of the event, while for the event 2 and $3 \mathrm{AR}$ and CARs are positive on the announcement date of the event in the 91 days estimation window, The results elaborates that two of the events in the telecom sector experienced positive ARs and CARs on the event date of M\&As.

Table 2. Differences in average abnormal and cumulative abnormal returns

\begin{tabular}{|c|c|c|c|c|c|}
\hline Event & & Event Day & Pre-event & Post- Event & Difference \\
\hline \multirow{2}{*}{$\begin{array}{l}\text { Event } 1 \text { (Pakistan Telecommunication } \\
\text { Company Limited - DVCOM Data (Pvt) } \\
\text { Limited) }\end{array}$} & Abnormal Return & $-0.41 \%$ & $-0.16 \%$ & $-0.33 \%$ & $-0.18 \%$ \\
\hline & $\begin{array}{l}\text { Cumulative Abnormal } \\
\text { Return }\end{array}$ & $-7.59 \%$ & $-7.18 \%$ & $-22.66 \%$ & $-15.48 \%$ \\
\hline \multirow{2}{*}{$\begin{array}{l}\text { Event } 2 \text { (Pakistan Telecommunication } \\
\text { Company Limited -Maskatiya } \\
\text { Communications (Pvt) Limited) }\end{array}$} & Abnormal Return & $0.06 \%$ & $0.08 \%$ & $0.06 \%$ & $-0.02 \%$ \\
\hline & $\begin{array}{l}\text { Cumulative Abnormal } \\
\text { Return }\end{array}$ & $3.79 \%$ & $3.73 \%$ & $6.59 \%$ & $2.86 \%$ \\
\hline \multirow[t]{2}{*}{$\begin{array}{l}\text { Event } 3 \text { (Worldcall Telecom Limited } \\
\text {-WorldCall Broadband Limited) }\end{array}$} & $\begin{array}{l}\text { Average Abnormal } \\
\text { Return }\end{array}$ & $7.97 \%$ & $-0.12 \%$ & $0.44 \%$ & $0.57 \%$ \\
\hline & $\begin{array}{l}\text { Cumulative Abnormal } \\
\text { Return }\end{array}$ & $2.39 \%$ & $-5.58 \%$ & $22.31 \%$ & $27.89 \%$ \\
\hline
\end{tabular}


Further, the table shows the results of ARs and CARs of 3 events of the study in the telecom sector. The result shows a negative effect on ARs and CARs after M\&As. The pre and post difference for the event 1 and 2 had negative Abnormal Returns (AR) in the 91 days event window. While the Cumulative Abnormal Returns (CAR) for the event 1 was found negative having a value of $-15.48 \%$. Event 2 and 3 had positive CARS having values of $2.86 \%$ and $27.89 \%$ respectively. The event 3 showed positive ARs after the announcement of M\&As but statistically insignificant.

The $t$ statistic values of all the events in the telecom sector are statistically insignificant as shown in Table 3 . For event 1 , the t-statistic value is -1.595 , and in event 2 , it's 1.039 and for the event 3 value is 0.712 . This confirms that results are statistically insignificant for the telecom sector and did not create value for the shareholders in the short run.

Table 3. T-statistics values of telecom Sector (Pakistan)

\begin{tabular}{lccc}
\hline & Average Abnormal return & Cumulative Abnormal Return & t-statistic \\
\hline & Telecom Sector & & -1.595 \\
Event 1 & $-0.25 \%$ & $-22.66 \%$ & 1.039 \\
E2 & $0.07 \%$ & $6.59 \%$ & 0.712 \\
E3 & $0.25 \%$ & $22.31 \%$ & \\
\hline
\end{tabular}

In the short run, it can be interpreted that the occurrence of M\&As affected negatively on the stock returns of the companies in the telecom sector, these observations correspond with the Cummins and Weiss ${ }^{(29)}$, as they also reported negative returns in a similar type of transactions. But, the results contradict the results of Flught ${ }^{(30)}$, Soongswang ${ }^{(31)}$ Wilcox et al $^{(20)}$ as their results conclude that M\&As had a positive impact on shareholders' wealth.

\subsection{Long Term Analysis}

The synergistic gain realization depends on the incorporation process and which may require a longer period to effectively realize this gain as it is believed that the companies need a longer time to adjust their assets, process, IT, etc. as performance does not change rapidly ${ }^{(32)}$. So, to extend the scope of this study, we analyzed the long term effect of these transactions on the shareholders' wealth. To achieve this objective, we measured the stock returns of the firms under study for 90 days, 180 days, 270 days and 360 days after the announcement of M\&As by using the BHAR approach.

In Table 4, After 90 days, Returns are $-24 \%,-13 \%$ and $25 \%$ for the event 1,2 and 3 respectively and $\mathrm{T}$ values for the events are $-1.471,-0.815$ and 0.886 , which are insignificant. Extending the event window the returns for the 180 days $-33 \%,-28 \%$ and $3 \%$ for the events and significance values for the event are $-1.780,1.201$ and 0.074 respectively. Only the event 1 significance value is significant at the $10 \%$ significant level while events 2 and 3 have insignificant results. Further, in the 270 days returns are $-48 \%,-39 \%$ and $62 \%$ and having t values $-1.986,-1.374$ and 1.432 , here event 1 has a significant value at the $5 \%$ significant level and event 2 and 3 values are insignificant. After 360 days the BHAR return is $-49 \%$ and $-65 \%$ and $36 \%$ for the event 1,2 and 3. Event 1 and 2 are significant having values of $-1.714,-1.812$ respectively at the significance level of $10 \%$, while the event 3 have insignificant values.

Table 4. Long term analysis of telecom sector of Pakistan

\begin{tabular}{|c|c|c|c|c|c|c|c|c|}
\hline Event & BHAR 9 & & BHAR 1 & & BHAR 2 & & BHAR 3 & \\
\hline & Return & T value & Return & T value & Return & T value & Return & T value \\
\hline $\begin{array}{l}\text { Event } 1 \text { (Pakistan Telecommu- } \\
\text { nication Company Limited - } \\
\text { DVCOM Data (Pvt) Limited) }\end{array}$ & $-24 \%$ & -1.471 & $-33 \%$ & $-1.780^{\star * \star}$ & $-48 \%$ & $-1.986^{\star *}$ & $-49 \%$ & $-1.714^{\star * *}$ \\
\hline $\begin{array}{lrr}\text { Event } 2 & \text { (Pakistan } & \text { Telecom- } \\
\text { munication } & \text { Company } & \text { Limited } \\
\text {-Maskatiya } & \text { Communications } \\
\text { (Pvt) Limited) } & \end{array}$ & $-13 \%$ & -0.815 & $-28 \%$ & -1.201 & $-39 \%$ & -1.374 & $-65 \%$ & $-1.812^{\star * *}$ \\
\hline $\begin{array}{l}\text { Event } 3 \text { (Worldcall Telecom Lim- } \\
\text { ited -WorldCall Broadband Lim- } \\
\text { ited) }\end{array}$ & $25 \%$ & 0.886 & $3 \%$ & 0.074 & $62 \%$ & 1.432 & $36 \%$ & 0.731 \\
\hline
\end{tabular}




\section{Conclusion \& Discussion}

The trend of M\&As in Pakistan started after 1998. Thereafter, the large number of M\&As events are witnessed every year in Pakistan. This growing trend can be seen in the Financial, industrial as well as Telecom industry of the country ${ }^{(33)}$. As per synergy theory, companies opt for M\&As for the purpose of growth, cost reduction, acquiring assets and business expansion into new markets leading towards enhanced firm performance to achieve profitability and to improve shareholders' wealth ${ }^{(4)}$.

This study aimed to review the firm performance in terms of shareholder's wealth in the telecom sector after the events of M\&As in this sector. The results of this study revealed that the occurrence of M\&As in the telecom industry negatively affected the shareholders' wealth in the short run in the estimation window of the 91 days. We extended the scope of this study by a longterm analysis, in which we measured the returns of the firm with the help of BHAR for 90, 180, 270 and 260 days respectively. Results were similar to the short-run study in the telecom sector and it is concluded that the market did not respond well to these events and did not create value for the shareholders in the long run.

The above results and conclusions suggest that the telecom sector of the country rather than going for M\&As deals should adopt different other ways to expand their businesses, as the results reject the synergy theory in the telecom sector of Pakistan. This may be due to various conditions depending on the nature of the occurrence of the event. This study has focused on the telecom sector of Pakistan to measure shareholders' returns in the short-run and long-run after the occurrence of M\&As. Further study can be done on measuring the financial stability of sectors with the help of financial ratios in telecom, banking as well as other sectors of the country. Future research can also be conducted by taking into account the human resources and acculturation perspective in the telecom and other sectors of the country.

\section{References}

1) Dutta S, Jog V. The long-term performance of acquiring firms: A re-examination of an anomaly. Journal of Banking \& Finance. 2009;33(8):1400-1412. Available from: https://dx.doi.org/10.1016/j.jbankfin.2009.02.004.

2) Fatima T, Shehzad A. Analysis of Impact of Merger and Acquisition of Financial Performance of banks: A case of Pakistan. Journal of Poverty, Investment and Development . 2014;5:29-36.

3) Mariappan V. Mergers and Acquisitions: The Human Issues and Strategies. Indian Journal of Industrial Relations. 2003;39(1):84-94.

4) Martynova M, Renneboog L. Mergers and acquisitions in Europe. Advances in corporate finance and asset pricing. 2006;p. 13-75.

5) Abbas Q, RS, EUH, MSI. Analysis of Pre and Post Merger and Acquisition Financial Performance of Banks in Pakistan. Information Management and Business Review. 2014;6(4):177-190. Available from: https://dx.doi.org/10.22610/imbr.v6i4.1113.

6) Akhtar S, Iqbal J. An empirical analysis of pre and post merger or acquisition impact on financial performance: a case study of Pakistan telecommunication limited. European Journal of Accounting Auditing and Finance Research. 2014;3(1):69-80.

7) Kumar BR. Wealth Creation in the World's Largest Mergers and Acquisitions: Integrated Case Studies. and others, editor;Springer. 2018.

8) Mellen CM, Evans FC. Valuation for M\&A: Building and Measuring Private Company Value. 2018.

9) Malkiel BG, Fama EF. Efficient capital markets: A review of theory and empirical work. The journal of Finance. 1970;25(2):383-417.

10) Tuch C, O'Sullivan N. The impact of acquisitions on firm performance: A review of the evidence. International Journal of Management Reviews. 2007;9(2):141-170. Available from: https://dx.doi.org/10.1111/j.1468-2370.2007.00206.x.

11) Ghosh A, Jain PC. Financial leverage changes associated with corporate mergers. Journal of Corporate Finance. 2000;6(4):377-402. Available from: https://dx.doi.org/10.1016/s0929-1199(00)00007-9.

12) Healy PM, Palepu KG, Ruback RS. Does corporate performance improve after mergers? Journal of Financial Economics. 1992;31(2):135-175. Available from: https://dx.doi.org/10.1016/0304-405x(92)90002-f.

13) Sharma DS, Ho J. The Impact of Acquisitions on Operating Performance: Some Australian Evidence. Journal of Business Finance \& Accounting. 2002;29(12):155-200. Available from: https://dx.doi.org/10.1111/1468-5957.00428.

14) Pawaskar V. Effect of Mergers on Corporate Performance in India. Vikalpa: The Journal for Decision Makers. 2001;26(1):19-32. Available from: https: //dx.doi.org/10.1177/0256090920010103.

15) Cosh A, Hughes A, Lee K, Singh A. 1996.

16) Mueller DC. and others, editor;Cambridge University Press. 1986.

17) Rani N, Yadav S, Jain P. Graduate School of System Design and Management Collaboration Complex. In: proceedings of Tenth Global Conference on Flexible Systems Management GLOGIFT10. 2010;p. 26-27.

18) Bashir A, Sajid R, Sheikh S. The Impact of Mergers and Acquisitions on Shareholders Wealth: Evidence from Pakistan. Journal of Scientific Research. 2011;8(1):261-265.

19) Faizan M, Khan I, Ilyas M. Impact of Mergers and Acquisitions on the Financial Performance of Bidding Banks in Pakistan. Global Social Sciences Review. 2019;4(3):342-50.

20) Wilcox HD, Chang KC, Grover V. Valuation of mergers and acquisitions in the telecommunications industry: a study on diversification and firm size. Information \& Management. 2001;38(7):459-471. Available from: https://dx.doi.org/10.1016/s0378-7206(00)00082-3.

21) Adnan A, Hossain A. Impact of M\&A announcement on acquiring and target firm's stock price: An event analysis approach. International Journal of Finance and Accounting. 2016;5(5):228-260.

22) Mahmood I, Aamir M, Hussain CM, Sohail N. Impact of merger/acquisition on share price-a case study of Pakistan. European Journal of Scientific Research. 2012;67(4):617-641.

23) Dodd P, Warner JB. On corporate governance: A study of proxy contests. Journal of financial Economics. 1983;11(1-4):401-439.

24) Brown SJ, Warner JB. Using daily stock returns: The case of event studies. Journal of financial economics. 1985;14(1):3-31.

25) Barber BM, Lyon JD. Detecting long-run abnormal stock returns: The empirical power and specification of test statistics. Journal of Financial Economics. 
1997;43(3):341-372. Available from: https://dx.doi.org/10.1016/s0304-405x(96)00890-2.

26) Corrado CJ. Event studies: A methodology review. Accounting \& Finance. 2011;51(1):207-234. Available from: https://dx.doi.org/10.1111/j.1467-629x. 2010.00375.x.

27) Kiesel F, Ries JM, Tielmann A. The impact of mergers and acquisitions on shareholders' wealth in the logistics service industry. International Journal of Production Economics. 2017;193:781-797. Available from: https://dx.doi.org/10.1016/j.ijpe.2017.09.006.

28) Schimmer M, Levchenko A, Müller S. Event Study Tools (Research Apps). St Gallen. 2015. Available from: http://wwweventstudytoolscomAccessedon.

29) Cummins JD, Weiss MA. Consolidation in the European Insurance Industry: Do Mergers and Acquisitions Create Value for Shareholders? BrookingsWharton Papers on Financial Services. 2004;2004(1):217-258. Available from: https://dx.doi.org/10.1353/pfs.2004.0001. doi:10.1353/pfs.2004.0001.

30) Flugt C. Shareholder wealth effects of mergers and acquisitions: An empirical investigation of short-term performance in the European market. Aarhus, Denmark. Aarhus School of Business. 2009.

31) Soongswang A. Total gains: do mergers and acquisitions pay investors in the event firms? Asian J Bus Manag Sci. 2011;1:136-185.

32) Hakkinen L, Hilmola OP. Integration and synergies of operations in horizontal M\&A. Inderscience Publishers. 2005. Available from: https://dx.doi.org/ 10.1504/ijmed.2005.006563. doi:10.1504/ijmed.2005.006563.

33) Tauseef S, Nishat M, Wealth, Of, Case, Banking P, et al. IBA Business Review. 2014;9(2). 